\title{
PENGARUH DISIPLIN KERJA DAN KOMPENSASI TERHADAP KINERJA KARYAWAN PADA PD. BUMI WIRALODRA INDRAMAYU
}

\author{
The Effect Of Work Discipline And Compensation On Employee Performance In Pd. \\ Bumi Wiralodra Indramayu
}

Meddy Nurpratama

meddy_nurpratama@yahoo.co.id

Manajemen Fakultas Ekonomi Unwir

\begin{abstract}
Human resources are a very important part for every company to achieve the goals to be achieved. Company goals can be achieved through high employee performance. The management of the company must be able to increase employee performance by paying attention to factors such as discipline and compensation. Results of research on company performance, PD. Bumi Wiralodra Indramayu in the 2013-2018 period experienced a decline in performance. This study aims to determine the effect of: work discipline on employee performance; compensation for employee performance; and the influence of work discipline and compensation together on employee performance in PD. Bumi Wiralodra Indramayu.

The method used in this study is associative, which aims to determine the relationship between two or more variables. Data collection techniques by means of field research, literature study, data analysis and a population of 30 people and the determination of the sample using total sampling. The data analysis follows descriptive analysis, normality test, multicollinearity and multiple regression analysis.

The results showed that work discipline had a significant effect on employee performance with a significance value of $0.000<0.05$; compensation has a significant effect on employee performance with a significance value of $0.006<0.05$. Work discipline and compensation together have a significant influence on employee performance in PD. Bumi Wiralodra Indramayu, a significance value of $0.000<0.05$ while the influence of work discipline and compensation on employee performance is $91.9 \%$. The remaining $8.1 \%$ is influenced by other factors.

Employee performance can be increased if discipline and compensation are considered by the company management. The enactment of regulations that are accompanied by appropriate sanctions will encourage high work discipline and the management of the company to try to meet the needs of employees through appropriate compensation.
\end{abstract}

Keywords: Work Discipline, Compensation and Employee Performance

\section{Pendahuluan}

Perkembangan usaha dewasa ini tidak hanya dituntut untuk mampu bersaing, namun juga dituntut agar mampu melakukan kegiatannya untuk jangka waktu yang panjang. Perusahaan merupakan sebuah organisasi yang bergerak dalam bidang jasa maupun barang, dimana organisasi atau perusahaan ini dapat berkembang dengan keuntungan yang diperoleh. Perusahaan baik perusahaan swasta maupun perusahaan milik pemerintah merupakan sebuah organisasi yang dibangun dan dikembangkan untuk mencapai tujuan organisasi.

Untuk mencapai tujuan organisasi, maka setiap perusahaan harus mempunyai sumber daya manusia yang berkualitas agar terjaminnya roda organisasi dapat berjalan dengan baik. Sumber daya manusia yang sangat penting adalah manusia karena manusia merupakan faktor penggerak organisasi dan tanpa manusia suatu perusahaan tidak akan berfungsi, sehingga pengelolaan sumber daya 
manusia yang baik merupakan asset dan berfungsi sebagai modal di dalam organisasi.

Perusahaan selalu berupaya untuk mendapatkan karyawan yang terlibat dalam kegiatan perusahaan dapat memberikan kontribusi yang baik. Dalam bentuk kinerja yang maksimal untuk mewujudkan tujuan yang telah ditetapkan sebelumnya. Kinerja pada dasarnya mencakup sikap mental yang selalu mempunyai pandangan bahwa kehidupan hari ini harus lebih baik dari hari kemarin dan hari esok harus lebih baik dari hari ini. Sikap yang demikian akan mendorong seseorang untuk tidak cepat merasa puas, akan tetapi harus mengembangkan diri dan meningkatkan kemampuan kerja dengan cara selalu mencari perbaikan-perbaikan dan peningkatan. Meningkatkan kinerja berarti bekerja lebih berkualitas dan tepat waktu. Dengan adanya kinerja ini diharapkan pekerjaan akan terlaksana sesuai dengan waktu yang telah ditentukan perusahaan sehingga dapat mencapai tujuan yang sudah ditetapkan.

$$
\text { Perusahaan Daerah (PD) Bumi }
$$

Wiralodra Indramayu adalah salah satu perusahaan milik daerah yang bergerak di bidang pertanian, perdagangan, pertambangan, gas dan jasa yang mempunyai banyak pesaing di bidang industri tersebut, sehingga kinerja perusahaan harus lebih baik dibandingkan perusahaan lain. Dalam proses pencapaian tujuan perusahaan, ada beberapa masalah yang menghambat PD. Bumi Wiralodra Indramayu dalam mencapai visi perusahaan. Masalah yang terjadi antara lain, masih ditemuinya karyawan yang belum mempunyai keterampilan yang diperlukan untuk menyelesaikan pekerjaannya dan masih ditemuinya karyawan yang bermalas-malasan dalam menjalankan tugasnya. Kondisi tersebut dapat menyebabkan kinerja perusahaan terganggu. Memperhatikan dari belum maksimalnya kinerja yang diharapkan oleh PD. Bumi Wiralodra Indramayu mengenai dari beberapa fenomena yang terjadi terkait dengan lemahnya disiplin kerja dan rendahnya kompensasi yang menjadi faktor penyebab kinerja yang dihasilkan kurang maksimal.

PD. Bumi Wiralodra Indramayu menuntut karyawannya untuk menyelesaikan pekerjaan dengan mutu yang baik. Untuk hal tersebut PD. Bumi Wiralodra Indramayu memberlakukan kebijakan jika karyawan mampu menyelesaikan pekerjaan dengan baik, cepat dan memenuhi syarat maka karyawan tersebut akan direkomendasikan untuk mendapatkan reward seperti kenaikan jabatan dilakukan setiap dua tahun sekali, membayarkan kompensasi yang sesuai dengan tingkat pekerjaan sehingga hubungan perusahaan dan 
karyawan dapat terjamin. Meskipun perusahaan telah berusaha untuk memberikan kompensasi sesuai dengan tingkat pekerjaan karyawan, namun masih ditemuinya karyawan yang tidak puas karena mendapatkan kompensasi yang rendah sehingga tidak memenuhi kebutuhan fisik karyawan. Perusahaan dalam hal ini harus mampu meningkatkan hasil pekerjaan para karyawannya yang akan berdampak pada kerja perusahaan yang semakin baik sehingga perusahaan dapat membayar kompensasi lebih besar kepada karyawannya.

PD. Bumi Wiralodra Indramayu pernah menetapkan sistem kebijakan kompensasi yaitu berupa bonus pada tahun 2013-2018 yang dapat dilihat pada tabel berikut:

Tabel 1

Pemberian Kompensasi dalam Bentuk Bonus di PD. Bumi Wiralodra Indramayu Tahun 2013-2018 dibagikan pada masing-masing bagian dengan persenan yang dipaparkan pada tabel 1. Namun, sejak tahun 2016 hingga sekarang perusahaan tidak lagi memberikan bonus kepada karyawannya hal ini dikarenakan kebijakan dari pimpinan PD. Bumi Wiralodra Indramayu yang mempertimbangkan pendapatan dari penjualan mengalami penurunan.

Gambar 1.1

Penjualan Produk Pupuk di PD. Bumi Wiralodra Indramayu Tahun 2013-2018

Dalam Juta Rupiah

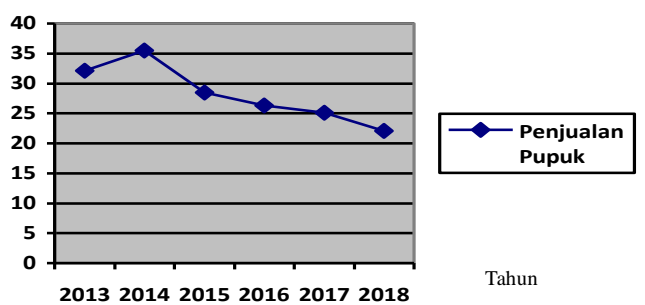

Sumber : PD. Bumi Wiralodra Indramayu, 2013-2018

Berdasarkan gambar di atas, nampak penurunan penjualan dari produk Pupuk PD. Bumi Wiralodra Indramayu,

\begin{tabular}{|l|c|c|c|c|c|c|}
\hline \multirow{2}{*}{ Bagian } & \multicolumn{7}{|c|}{ Tahun } \\
\cline { 2 - 7 } & $\mathbf{2 0 1 3}$ & $\mathbf{2 0 1 4}$ & $\mathbf{2 0 1 5}$ & $\mathbf{2 0 1 6}$ & $\mathbf{2 0 1 7}$ & $\mathbf{2 0 1 8}$ \\
\hline $\begin{array}{l}\text { Direktur } \\
\text { utama }\end{array}$ & $25 \%$ & $25 \%$ & $25 \%$ & - & - & \\
\hline $\begin{array}{l}\text { Direktur } \\
\text { Bidang }\end{array}$ & $20 \%$ & $20 \%$ & $20 \%$ & - & - & \\
\hline Ketua & $16 \%$ & $16 \%$ & $16 \%$ & - & - & \\
\hline Sekretaris & $14 \%$ & $14 \%$ & $14 \%$ & - & - & \\
\hline $\begin{array}{l}\text { Kepala } \\
\text { Bagian }\end{array}$ & $15 \%$ & $15 \%$ & $15 \%$ & - & - & \\
\hline $\begin{array}{l}\text { Karyawan } \\
\text { tetap }\end{array}$ & $4 \%$ & $4 \%$ & $4 \%$ & - & - & \\
\hline Anggota & $3 \%$ & $3 \%$ & $3 \%$ & - & - & \\
\hline Honor & $3 \%$ & $3 \%$ & $3 \%$ & - & - & \\
\hline
\end{tabular}
dimana awalnya yaitu pada tahun 2013 2014 mengalami kenaikan dari 32,1 juta menjadi 35,7 juta namun pada tahun-tahun berikutnya mengalami penurunan sampai tahun 2018 menjadi 20,5 juta.

Kompensasi merupakan salah satu aspek paling penting dan sensitif di dalam hubungan kerja. Setiap karyawan yang Dari Tabel 1 menunjukkan bahwa persentase bonus pada masing-masing posisi yang merupakan alokasi dari $10 \%$ laba bersih perusahaan, kemudian sudah bekerja maka perusahaan sewajarnya menghargai jerih payah karyawan itu dengan memberi balas jasa yang setimpal kepada mereka. Kompensasi jika dikelola dengan baik dapat membantu 
dalam penguatan terhadap nilai-nilai kunci organisasi serta meningkatkan kinerja yang optimal yang pada akhirnya akan mendukung terhadap pencapaian tujuan organisasi.

Berkaitan dengan kedisiplinan yang diterapkan oleh PD. Bumi Wiralodra Indramayu masih ditemuikan beberapa karyawan yang terlambat masuk kerja, pulang lebih cepat dari jam yang sudah ditetapkan dan masih ditemuinya karyawan yang berada di luar kantor saat jam kerja berlangsung. Dalam hal ini sangsi hukuman yang diberikan masih rendah sehingga diperlukan adanya pengawasan yang ketat dan juga ketegasan dari pimpinan dalam meningkatkan kedisplinan.

Faktor penting lainnya adalah disiplin kerja. Disiplin kerja dapat dilihat sebagai sesuatu yang besar manfaatnya, baik bagi kepentingan organisasi maupun bagi para karyawan. Bagi organisasi, adanya disipling kerja akan menjamin terpeliharanya tata tertib dan kelancaran pelaksanaan tugas, sehingga diperoleh hasil yang optimal. Adapun bagi karyawan akan diperoleh suasana kerja yang menyenangkan sehingga akan menambah semangat kerja dalam melaksanaan pekerjaannya.

Berdasarkan data yang berada di lapangan menunjukan bahwa ada fenomena menarik yang terjadi di PD.
Bumi Wiralodra Indramayu pada lima tahun kebelakang yaitu masih terdapatnya karyawan yang alpha bekerja. Kedisiplinan karyawan dapat dilihat dari kehadiran atau absensi karyawan. Karyawan yang absen di PD. Bumi Wiralodra Indramayu dari tahun 2015 sampai dengan tahun 2018 selalu ada karyawan yang tidak masuk kerja dengan jumlah yang relatif tidak terlalu banyak. Alasan absen diantaranya karena ijin, sakit, alpha dan cuti. Dari tahun 2015-2018, jumlah yang absen paling banyak terjadi pada tahun 2018, yaitu karena ijin 3 orang (10\%), sakit 4 orang $(13,33 \%)$, dan alpha 3 orang $(10,00 \%)$. Hal ini menunjukan bahwa masih terjadinya karyawan yang absen karena alpha di PD. Bumi Wiralodra Indramayu. Dengan adanya kedisiplinan diharapkan pekerjaan akan diselesaikan tepat waktu. Bilamana kedisiplinan tidak dapat ditegakkan maka kemungkinan tujuan yang telah ditetapkan tidak dapat dicapai. Apabila suatu perusahaan hanya memperhatikan tentang pendidikan, keahlian dan teknologi tanpa memikirkan semangat dan disiplin kerja karyawan, maka pendidikan, keahlian dan teknologi yang tinggi sekalipun tidak akan menghasilkan kinerja yang maksimal bila karyawan yang bersangkutan tidak dapat memanfaatkannya secara teratur dan mempunyai kesungguhan disiplin kerja yang tinggi. 
Meddy Nurpratama

Kinerja perusahaan sangat tergantung oleh kinerja bawahannya, oleh karena itu perusahaan menetapkan standar yang harus dicapai oleh setiap karyawannya. Rata-rata hasil penilaian seluruh karyawan yang mengikuti penilaian kinerja. Adanya perbandingan dalam hasik kinerja di PD. Bumi Wiralodra Indramayu. Dapat dilihat bagian objek hasil kinerja yang paling rendah adalah bagian kualitas/kuantitas kerja yaitu $75,1 \%$ atau kurang dari $24,9 \%$ dari skala penilaian $(100 \%)$. Hal ini dapat menunjukkan bahwa adanya penurunan kualitas kerja diantara karyawan sehingga menurunnya kinerja karyawan yang berdampak pada kinerja perusahaan.

Menurut penelitian Febyolla Presilawati (2016) dengan judul Pengaruh Kompensasi dan Disiplin Kerja Terhadap Kinerja Guru SMAN Negeri 6 Banda Aceh menunjukkan bahwa terdapat pengaruh kompensasi dan disiplin kerja terhadap kinerja guru dan koefisien regresi variabel kompensasi adalah 0.248, hal ini konstan maka setiap peningkatan variabel kompensasi maka dapat diprediksi bahwa variabel kinerja ikut naik 0.248. Koefisien regresi variabel disiplin kerja adalah 0.738 , hal ini konstan maka setiap peningkatan variabel disiplin kerja naik maka dapat diprediksi bahwa variabel kinerja ikut naik 0.738. Juga hasil penelitian Hamlan Daily (2015) dengan judul Pengaruh
Kompetensi, Disiplin dan Kompensasi Terhadap Kinerja Pegawai Badan Pemberdayaan Perempuan dan Keluarga Berencana Daerah Provinsi Sulawesi Tengah menunjukkan bahwa secara simultan variabel disiplin dan kompensasi berpengaruh terhadap kinerja karyawan.

Berdasarkan beberapa penelitian sebelumnya tersebut, menunjukkan makna bahwa disiplin kerja dan kompensasi merupakan variabel yang dapat mempengaruhi kinerja. Meskipun dari beberapa hasil penelitian tersebut masih menunjukkan hasil yang tidak konsisten, sehingga penulis tertarik untuk melakukan penelitian ini dengan judul "Pengaruh Disiplin Kerja dan Kompensasi Terhadap Kinerja Karyawan Pada PD. Bumi Wiralodra Indramayu."

\section{Metodologi Penelitian}

Obyek dalam penelitian ini adalah di PD. Bumi Wiralodra Indramayu, sedangkan subyek penelitiannya adalah karyawan yang bekerja di PD. Bumi Wiralodra Indramayu untuk mengetahui dan menganalisis pengaruh disiplin kerja dan kompensasi terhadap kinerja karyawan pada PD. Bumi Wiralodra Indramayu. Penelitian ini menggunakan jenis penelitian asosiatif.

Dalam penelitian ini yang menjadi variabel independen adalah disiplin kerja $\left(\mathrm{X}_{1}\right)$ dan kompensasi $\left(\mathrm{X}_{2}\right)$. Sedangkan 
variabel dependen dalam penelitian ini adalah kinerja karyawan (Y). Karena jumlah populasi relatif sedikit, maka sampel pada penelitian ini adalah seluruh karyawan di PD. Bumi Wiralodra Indramayu, yang berjumlah sebanyak 30 orang. Adapun teknik sampling yang akan digunakan yaitu dengan total sampling, yang artinya seluruh anggota populasi dijadikan sampel penelitian.

Penulis menggunakan cara pengumpulan data melalui studi pustaka, observasi, dokumentasi dan kuesioner. Sebelum melakukan pengolahan data, terlebih dahulu diuji kesahihan dan keandalannya. Untuk itu, dilakukan pengujian data dari keseluruhan pernyataan pada kuesioner dengan uji validitas dan reliabilitas.

Pada analisa data dilakukan uji asumsi klasik meliputi uji normalitas dan multikolinieritas. Adapun analisis regresi yang dilakukan analisis regresi berganda dan uji hopotesisnya meliputi uji t (parsial) dan uji F (simultan).

\section{Uji Asumsi}

Uji asumsi yang dilakukan meliputi uji normalitas dan uji multikolinearitas. Uji ini dilakukan untuk memperoleh nilai pengukuran yang tidak bias dan efisien dari suatu persamaan regresi linear berganda yang harus memenuhi asumsi uji tersebut.

\section{a. Uji Normalitas}

Hasil uji normalitas dapat dilihat pada tabel berikut:

Tabel 3

Hasil Uji Normalitas

Tests of Normality

\begin{tabular}{|l|r|r|r|r|r|r|}
\hline & \multicolumn{4}{|c|}{ Kolmogorov-Smirnov } & \multicolumn{3}{|c|}{ Shapiro-Wilk } \\
\cline { 2 - 7 } & Statistic & \multicolumn{1}{c|}{ df } & \multicolumn{1}{c|}{ Sig. } & Statistic & df & \multicolumn{1}{c|}{ Sig. } \\
\hline Disiplin kerja & .113 & 30 & $.200^{*}$ & .962 & 30 & .349 \\
Kompensasi & .127 & 30 & $.200^{*}$ & .967 & 30 & .472 \\
Kinerja & .119 & 30 & $.200^{*}$ & .950 & 30 & .165 \\
karyawan & & & & & \\
\hline
\end{tabular}

*. This is a lower bound of the true significance.

a. Lilliefors Significance Correction

Pengujian statistik menggunakan uji statistik non-paramatrik Shapiro-Wilk menunjukan nilai 0,349 (disiplin kerja), nilai 0.472 (kompensasi) dan nilai 0,165 (kinerja karyawan) atau secara keseluruhan nilai signifikansi $>0,05$. Maka dapat disimpulkan bahwa seluruh variabel berdistribusi normal. Artinya asumsi normalitas dalam analisis ini terpenuhi.

\section{b. Uji Multikolinearitas}

Tujuan untuk menguji apakah ada pada model regresi ditemukan adanya korelasi antar variabel independen. Jika terjadi, maka dinamakan terdapat problem multikolinearitas (multiko). Model regresi yang baik tidak terajdi korelasi antar variabel independen.

Tabel 4

Hasil Uji Multikolinearitas

\begin{tabular}{|c|c|c|c|c|c|c|c|}
\hline \multicolumn{8}{|c|}{ Coefficients $^{\mathrm{a}}$} \\
\hline \multirow[t]{2}{*}{ Model } & \multicolumn{2}{|c|}{$\begin{array}{l}\text { Unstandardize } \\
\text { d Coefficients }\end{array}$} & $\begin{array}{l}\text { Stand } \\
\text { ardize }\end{array}$ & \multirow[t]{2}{*}{$\mathrm{t}$} & \multirow[t]{2}{*}{ Sig. } & \multicolumn{2}{|c|}{$\begin{array}{l}\text { Collinearity } \\
\text { Statistics }\end{array}$} \\
\hline & B & $\begin{array}{l}\text { Std. } \\
\text { Error }\end{array}$ & Beta & & & $\begin{array}{c}\text { Tolera } \\
\text { nce }\end{array}$ & VIF \\
\hline (Constant) & 3.238 & 1.600 & & 2.023 & .053 & & \\
\hline $\begin{array}{l}\text { Disiplin } \\
\text { kerja }\end{array}$ & .931 & .114 & .733 & 8.150 & .000 & .119 & 8.408 \\
\hline
\end{tabular}


Meddy Nurpratama

\begin{tabular}{|l|r|r|r|r|r|r|r}
\hline $\begin{array}{l}\text { Kompensa } \\
\text { si }\end{array}$ & .232 & .078 & .266 & 2.960 & .006 & .119 & 8.408 \\
\hline
\end{tabular} a. Dependent Variable: Kinerja karyawan

\section{Coefficient variabel dependen}

kinerja karyawan terlihat untuk kedua variabel independen, angka VIF $=8,403 \mathrm{di}$ bawah angka 10 dan angka Tolerance 0,119 berkisar diangka 1. Dengan demikian, dapat disimpulkan model regresi tersebut tidak terdapat problem multikolinearitas.

\section{c. Analisis Regresi Berganda}

Untuk melihat pengaruh disiplin kerja dan kompensasi secara bersama-sama (simultan) terhadap kinerja karyawan, dapat dilihat pada hasil perhitungan SPSS 25.0 for windows dalam model summary di bawah ini.

Tabel 5

Hasil Regresi Berganda Variabel Disiplin Kerja (X1) dan Kompensasi (X2) terhadap Kinerja karyawan (Y)

\section{Coefficients $^{\mathrm{a}}$}

\begin{tabular}{|c|c|c|c|c|c|c|}
\hline \multirow{2}{*}{\multicolumn{2}{|c|}{ Model }} & \multicolumn{2}{|c|}{$\begin{array}{l}\text { Unstandardized } \\
\text { Coefficients }\end{array}$} & \multirow{2}{*}{$\begin{array}{c}\text { Standardiz } \\
\text { ed } \\
\text { Coefficien } \\
\text { ts }\end{array}$} & \multirow[t]{2}{*}{$\mathrm{t}$} & \multirow[t]{2}{*}{ Sig. } \\
\hline & & B & $\begin{array}{l}\text { Std. } \\
\text { Error }\end{array}$ & & & \\
\hline \multirow{3}{*}{1} & (Constant) & 3.238 & 1.600 & & 2.023 & .053 \\
\hline & $\begin{array}{l}\text { Disiplin } \\
\text { kerja }\end{array}$ & .931 & .114 & .733 & 8.150 & .000 \\
\hline & Kompensasi & .232 & .078 & 266 & 2.960 & $.006^{1}$ \\
\hline
\end{tabular}

a. Dependent Variable: Kinerja karyawan

Persamaan regresi : $\mathrm{Y}=3,238+0,931 \mathrm{X}_{1}+$ $0,232 X_{2}$

a. Konstanta sebesar 3,238 menyatakan bahwa jika tidak ada disiplin kerja dan kompensasi, maka kinerja karyawan sebesar 3,238.
Koefisien regresi sebesar 0,931 menyatakan bahwa setiap kenaikan satu satuan tingkat disiplin kerja akan meningkatkan kinerja karyawan sebesar 0,931 .

c. Koefisien regresi sebesar 0,232 menyatakan bahwa setiap kenaikan satu satuan tingkat kompensasi akan meningkatkan kinerja karyawan sebesar 0,232 .

\section{Tabel 6}

Koefisien Regresi Berganda

Disiplin Kerja (X1) dan Kompensasi (X2) terhadap Kinerja karyawan (Y)

Model Summary

\begin{tabular}{|l|c|r|r|r|r|}
\hline $\begin{array}{l}\text { Mo } \\
\text { del }\end{array}$ & \multicolumn{1}{c|}{$\mathrm{R}$} & $\begin{array}{c}\text { R } \\
\text { Square }\end{array}$ & $\begin{array}{c}\text { Adjusted } \\
\text { R Square }\end{array}$ & $\begin{array}{c}\text { Std. Error of } \\
\text { the Estimate }\end{array}$ & $\begin{array}{c}\text { Durbin- } \\
\text { Watson }\end{array}$ \\
\hline 1 & $.961^{\mathrm{a}}$ & .924 & .919 & 1.21772 & 1.484 \\
\hline
\end{tabular}

a. Predictors: (Constant), Kompensasi, Disiplin kerja

b. Dependent Variable: Kinerja karyawan

$$
\text { Angka } \quad \mathrm{R} \quad \text { sebesar } \quad 0,961
$$

menunjukkan bahwa korelasi antara disiplin kerja dan kompensasi dengan kinerja karyawan adalah sangat kuat. Besarnya angka adjusted $R$ square adalah ф,919. Angka tersebut menunjukkan 中esarnya pengaruh disiplin kerja dan fompensasi secara simultan terhadap inerja karyawan adalah 91,9\%. Adapun sisanya $8,1 \%$ dipengaruhi oleh faktor lain.

\section{Uji Hipotesis}

\section{a. Uji Secara Parsial}

Uji parsial menggunakan uji t yaitu suatu uji untuk mengetahui signifikansi pengaruh variabel independen (disiplin 
Meddy Nurpratama

kerja dan kompensasi) secara parsial atau individual menerangkan variabel dependen (kinerja karyawan). Pengujian ini menggunakan SPSS 25 dengan hasil sebagai berikut:

Tabel 7

Hasil Uji t

Coefficients $^{\mathrm{a}}$

\begin{tabular}{|c|c|c|c|c|c|}
\hline \multirow{2}{*}{\multicolumn{2}{|c|}{ Model }} & \multicolumn{2}{|c|}{$\begin{array}{l}\text { Unstandardized } \\
\text { Coefficients }\end{array}$} & \multirow{2}{*}{$\begin{array}{c}\text { Standardiz } \\
\text { ed } \\
\text { Coefficien } \\
\text { ts }\end{array}$} & \multirow[t]{2}{*}{$\mathrm{t}$} \\
\hline & & B & $\begin{array}{l}\text { Std. } \\
\text { Error }\end{array}$ & & \\
\hline \multirow{3}{*}{1} & (Constant) & 3.238 & 1.600 & & 2.023 \\
\hline & $\begin{array}{l}\text { Disiplin } \\
\text { kerja }\end{array}$ & .931 & .114 & .733 & 8.150 \\
\hline & $\begin{array}{l}\text { Kompensa } \\
\text { si }\end{array}$ & .232 & .078 & .266 & 2.960 \\
\hline
\end{tabular}

$\mathrm{H}_{0}: \mathrm{r}=0$ : Tidak ada pengaruh secara signifikan antara disiplin kerja dan kompensasi terhadap kinerja karyawan.

$\mathrm{H}_{0}: \mathrm{r} \neq 0$ : Ada pengaruh secara signifikan antara disiplin kerja dan kompensasi terhadap kinerja karyawan.

Hasil uji t adalah sebagai berikut:

1) Dari tabel 4.24 dapat kita lihat bahwa nilai $t_{\text {hitung }}$ pada variabel disiplin kerja adalah sebesar 8.150 dengan tingkat signifikansi sebesar 0,000. Karena nilai $t_{\text {hitung }}>\mathrm{t}_{\text {tabel }}$ yaitu $8.150>1,701$ dan nilai signifikansi $0,000<0,05$, maka $\mathrm{H}_{0}$ ditolak dan Ha diterima. Hal ini berarti terdapat pengaruh secara signifikan disiplin kerja berpengaruh terhadap kinerja karyawan.

2) Dari tabel 4.24 dapat kita lihat bahwa nilai thitung pada variabel kompensasi adalah sebesar 2.960 dengan tingkat signifikansi sebesar 0,006. Karena nilai $\mathrm{t}_{\text {hitung }}>\mathrm{t}_{\text {tabel }}$ yaitu $2.960>1,701$ dan nilai signifikansi $0,006<0,05$, maka $\mathrm{H}_{0}$ ditolak dan Ha diterima. Hal ini berarti terdapat pengaruh secara signifikan kompensasi berpengaruh terhadap kinerja karyawan.

\section{Uji Secara Simultan}

Hipotesis yang diajukan adalah menguji apakah variabel disiplin .000 erja dan kompensasi secara bersama-sama .006 erpengaruh positif dan signifikan terhadap kinerja karyawan digunakan uji F. Adapun langkah-langkah analisisnya dapat dilakukan sebagai berikut:

1) Hipotesis statistik / operasional

Ho : $r=0$, artinya tidak terdapat pengaruh antara disiplin kerja dan kompensasi secara bersama-sama terhadap kinerja karyawan.

Ho $: r \neq 0$, artinya terdapat pengaruh antara disiplin kerja dan kompensasi secara bersama-sama terhadap kinerja karyawan.

2) Menghitung $F_{\text {hitung }}$

\section{Tabel 8}

Anova Uji F

ANOVA $^{\mathrm{a}}$

\begin{tabular}{|c|c|c|c|c|c|}
\hline Model & $\begin{array}{l}\text { Sum of } \\
\text { Squares }\end{array}$ & $\mathrm{df}$ & $\begin{array}{c}\text { Mean } \\
\text { Square }\end{array}$ & $\mathrm{F}$ & Sig. \\
\hline $\begin{array}{l}\text { Regressi } \\
\text { on } \\
\text { Residual } \\
\text { Total }\end{array}$ & $\begin{array}{r}580.397 \\
15.469 \\
595.867\end{array}$ & $\begin{array}{r}2 \\
27 \\
29\end{array}$ & $\begin{array}{r}290.199 \\
.573\end{array}$ & $\begin{array}{r}56.51 \\
2\end{array}$ & $.000^{\mathrm{b}}$ \\
\hline
\end{tabular}


Meddy Nurpratama

Hasil penghitungan SPSS 25.0 for windows diperoleh nilai $\mathrm{F}$ hitung sebesar 56.512.

3) Menghitung $F_{\text {tabel }}$

Ketentuan: Taraf signifikansi 0,05 dengan derajat kebebasan ( $d k 1)$ numerator = jumlah variabel -1 atau $3-1=2$ dan derajat kebebasan ( $d k 2)$ enumerator = jumlah kasus - jumlah variabel $=30-2=$ 28. Dengan ketentuan tersebut, diperoleh nilai $\mathrm{F}_{\text {tabel }}$ sebesar 3,34.

4) Kriteria

Jika $\mathrm{F}_{\text {hitung }}>\mathrm{F}_{\text {tabel, }}$, maka Ho ditolak dan Ha diterima.

Jika $F_{\text {hitung }}<F_{\text {tabel, }}$ maka Ho diterima dan Ha ditolak.

\section{Kesimpulan}

Dari hasil penelitian didapatkan

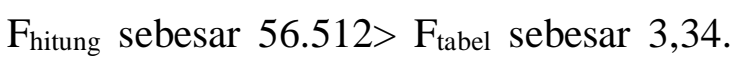
Dengan demikian, Ho ditolak dan $\mathrm{Ha}$ diterima. Artinya adanya pengaruh yang positif dan signifikan antara disiplin keija dan kompensasi secara bersama-sama terhadap kinerja karyawan.

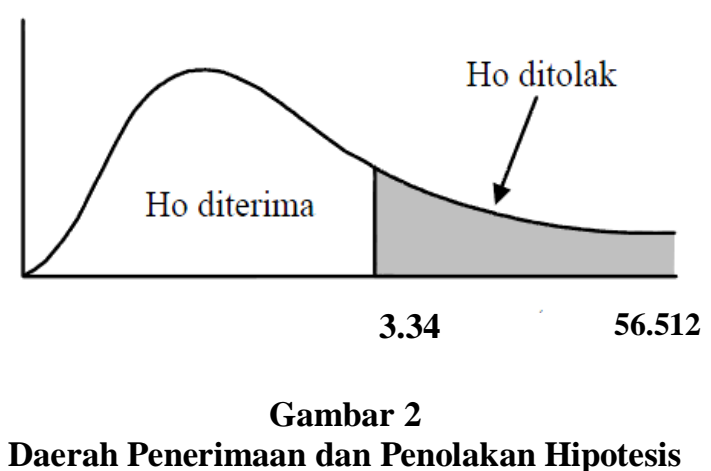

Kesimpulan

Berdasarkan uraian yang peneliti kemukakan pada bab sebelumnya, maka peneliti menarik kesimpulan sebagai berikut:

a. Terdapat pengaruh secara signifikan disiplin kerja berpengaruh terhadap kinerja karyawan yang dibuktikan dengan nilai $t_{\text {hitung }}>\mathrm{t}_{\text {tabel }}$ yaitu 8,150> 1,701 dan nilai signifikansi $0,001<$ 0,05 .

b. Terdapat pengaruh secara signifikan kompensasi berpengaruh terhadap kinerja karyawan yang dibutkikan dengan nilai $t_{\text {hitung }}>t_{\text {tabel }}$ yaitu 2,960 > 1,701 dan nilai signifikansi $0,000<$ 0,05 .

c. Adanya pengaruh yang positif dan signifikan antara disiplin keija dan kompensasi secara bersama-sama terhadap kinerja karyawan. Dengan kata lain, tingginya disiplin kerja dan kompensasi, menyebabkan tingginya kinerja karyawan pada PD. Bumi Wiralodra Indramayu dan besarnya pengaruh disiplin kerja dan kompensasi secara simultan terhadap kinerja karyawan adalah 91,9\%.

\section{Saran}

a. PD. Bumi Wiralodra Indramayu perlu mempertahankan dan melaksanakan pedoman kerja yang jelas untuk semua 
Meddy Nurpratama

karyawan, sehingga masing-masing karyawan mengetahui tugas dan kewajibannya serta meningkatkan kedisiplinan masing-masing bagian kerja.

b. PD. Bumi Wiralodra Indramayu perlu memberlakukan sanksi hukuman harus diberlakukan sama rata kepada semua karyawan yang melanggar peraturanperaturan perusahaan, maka sikap dan perilaku indisipliner karyawan akan berkurang, serta perlunya pemberian insentif yang berkelanjutan, karena insentif ini akan membuat karyawan lebih semangat dan meningkatkan kinerja karyawan.

c. Diperlukan penelitian lanjutan tentang faktor-faktor lain yang mempunyai pengaruh terhadap kinerja diluar disiplin kerja dan kompensasi. Penelitian lanjutan ini sangat diperlukan untuk mengidentifikasi faktor- faktor lain secara positif benar-benar menjadi unsur determinan terhadap pencapaian kinerja karyawan. Dengan mengidentifikasi faktor lain, maka akan memudahkan meningkatkan kinerja karyawan pada PD. Bumi Wiralodra Indramayu.

\section{DAFTAR PUSTAKA}

Ananta Dwikristianto Satedjo dan Sesilya Kempa. 2017. Pengaruh Kompensasi dan Disiplin Kerja Terhadap Kinerja Karyawan PT. Modern Widya Tehnical Cabang Jayapura. e-Jurnal Katalogis, Volume 3 Nomor 1, Januari 2015 hlm 84-94.

Astadi Pangarso. 2016. Pengaruh Disiplin Kerja Terhadap Kinerja Karyawan di Biro Pelayanan Sosial Dasar Sekretariat Daerah Provinsi Jawa Barat. Jurnal Manajemen Teori dan Terapan Tahun 9. No. 2, Agustus 2016

Badriyah, M. 2015. Manajemen Sumber Daya Manusia. Bandung: Penerbut Pustaka Setia.

Edrick Leonardo dan Fransisca Andreani. 2015. Pengaruh Pemberian Kompensasi Terhadap Kinerja Karyawan Pada PT. Kopanitia. AGORA Vol. 3, No. 2, 2015.

Febyolla Presilawati. 2016. Pengaruh Kompensasi dan Disiplin Kerja Terhadap Kinerja Guru SMAN Negeri 6 Banda Aceh. Jurnal Visioner \& Strategis, Volume 5, Nomor 2, September 2016.

Hamlan Daily. 2015. Pengaruh Kompetensi, Disiplin dan Kompensasi Terhadap Kinerja Pegawai Badan Pemberdayaan Perempuan dan Keluarga Berencana Daerah Provinsi Sulawesi Tengah. AGORA Vol. 5, No. 3, (2017).

Handoko, T. Hani. 2014. Manajemen Personalia dan Sumberdaya Manusia. Yogyakarta: BPFE. 
Hasibuan, Malayu S.P. 2014. Manajemen Sumber Daya Manusia. Jakarta: Bumi Aksara.

Jeli Nata Liyas. 2017. Pengaruh Disiplin Kerja Terhadap Kinerja Karyawan Pada Bank Perkreditan Rakyat. Al Masraf: Jurnal Lembaga Keuangan dan Perbankan-Volume 2, Nomor 1, Januari-Juni 2017.

Mailiana. 2016. Pengaruh Disiplin Kerja Terhadap Kinerja Pegawai Dinas Pengelolaan Pasar Kota Bajarmasin. Jurnal Ekonomi Manajemen Vol. 10 No. 1, Januari 2016.

Mangkunegara, A. A. Anwar Prabu. 2015, Manajemen Sumber Daya Manusia Perusahaan. Bandung: Penerbit Pt. Remaja Rosdakarya.

Notoatmodjo, $\quad$ Soekidjo. 2009. Pengembangan Sumber Daya Manusia. Jakarta: PT. Rineka Cipta.

Rivai, Veithzal. 2011. Manajemen Sumber Daya Manusia Untuk Perusahaan Dari Teori Ke Praktik. Jakarta: PT Raja Grafindo Persada.

Samsudin, Sadili. 2006. Manajemen Sumber Daya Manusia. Penerbit: CV Pustaka Setia.

Sedarmayanti. 2009. Sumber Daya Manusia dan Produktivitas Kerja. Bandung: CV. Mandar Maju.

Sedarmayanti. 2011. Tata Kerja dan Kinerja Karyawan. Bandung: Penerbit Mandar Maju.

Sedarmayanti. 2016. Manajemen Sumber Daya Manusia, Reformasi Birokrasi dan Manajemen
Karyawan Negeri Sipil. Bandung: PT. Refika Aditama.

Siagian, Sondang. 2010. Organisasi, Kepemimpinan, Perilaku Administrasi. Jakarta: CV. Haji Mas Agung.

Simamora, Henry. 2012. Akuntansi Manajemen. Jakarta: Star Gate Publisher.

Stefanus Andi Pratama. 2015. Pengaruh Kompensasi Terhadap Kinerja Karyawan (Studi pada karyawan PT. Asuransi Jiwasraya persero regional office Malang). Jurnal Administrasi Bisnis (JAB)|Vol. 25 No. 1 Agustus 2015.

Sugiyono. 2010. Metode Peneitian Bisnis (Pendekatam Kuantitatif, Kualitatif dan $R \& D)$. Bandung: Penerbit Alfabeta.

Sugiyono. 2015. Metode Penelitian Manajemen. Bandung: Alfabeta.

Sutrisno, Edi. 2016. Manajemen Sumber Daya Manusia. Jakarta: Prenadamedia Group.

Umar, Husein. 2014. Metode Penelitian untuk Skripsi dan Tesis Bisnis. Jakarta: PT. Raja Grafindo.

Usman Fauzi. 2014. Pengaruh Kompensasi Terhadap Kinerja Karyawan Pada PT. Trakindo Utama Samarinda. eJournal Ilmu Administrasi Bisnis, 2014, 2 (3) : 172 - 185. 